FIU Law Review

Spring 2010

\title{
Private Injuries, Public Policies: Adjusting the NLRB's Approach to Backpay Remedies
}

James J. Brudney

The Ohio State University Moritz College of Law

Follow this and additional works at: https://ecollections.law.fiu.edu/lawreview

Part of the Other Law Commons

Online ISSN: 2643-7759

\section{Recommended Citation}

James J. Brudney, Private Injuries, Public Policies: Adjusting the NLRB's Approach to Backpay Remedies, 5 FIU L. Rev. 645 (2010).

DOI: https://dx.doi.org/10.25148/lawrev.5.2.17

This Article is brought to you for free and open access by eCollections. It has been accepted for inclusion in FIU Law Review by an authorized editor of eCollections. For more information, please contact lisdavis@fiu.edu. 


\title{
Private Injuries, Public Policies: Adjusting the NLRB's Approach to Backpay Remedies
}

\author{
James J. Brudney*
}

\section{INTRODUCTION}

The Symposium theme of re-engineering the National Labor Relations Board encompasses two propositions. First, the National Labor Relations $\operatorname{Act}^{1}$ (NLRA or Act) is in dire need of reform. After decades of congressional gridlock, however, the prospects for passage of the Employee Free Choice $\mathrm{Act}^{2}$ are at best uncertain. And even if this major bill is enacted in the form it was introduced, numerous labor relations challenges under the NLRA would remain unaddressed. ${ }^{3}$ Meanwhile, the Labor Board continues to administer the Act, too often operating at depleted strength and periodically censured as isolated and politicized, or as not sufficiently engaged with the complexities and challenges of the modern workplace. ${ }^{4}$

* James J. Brudney is the Newton D. Baker-Baker \& Hostetler Chair in Law at The Ohio State University Moritz College of Law. Professor Brudney is grateful to Aaron Cornell and Melanie Oberlin for superb research assistance and to Jennifer Pursell for excellent secretarial support. Elizabeth Kilpatrick, John Ferguson, and others at the NLRB furnished essential data on backpay claims as well as invaluable information on Board practices. Marshall Babson provided helpful critical feedback at the Symposium held at Florida International University College of Law in Miami in March of 2010. The arguments and proposals in this article do not in any way reflect the views or preferences of current or former Board personnel. The author states that errors of commission or omission are his alone. The Ohio State University Moritz College of Law contributed generous financial assistance.

1 National Labor Relations Act, Pub. L. No. 74-198, 49 Stat. 449 (codified as amended at 29 U.S.C. $\S \S 151-169(2006))$.

2 See Employee Free Choice Act, S. 560, H.R. 1409, 111 th Cong. (2009).

See, e.g., Re-Empowerment of Skilled and Professional Employees and Construction Tradeworkers Act, S. 969, 110th Cong. (2007) (proposing to amend NLRA definition of supervisor); Employee Misclassification Prevention Act, S. 3648, 110th Cong. (2008) (creating special penalty for employers who misclassify employees as non-employees); H.R. 3408, 111th Cong. (2009) (proposing to close tax code loophole on employer classification of workers); S. 2882, 111th Cong. (2010) (proposing to close tax code loophole on employer classification of workers).

4 In terms of operating at depleted strength, the Board was initially reduced to two members from November 1993 to January 1994, then, again from December 2001 to January 2002, and for several days in August 2005. Most recently, it operated with only two members from December 2007 to April 2010, a period of more than two years. See Brief for NLRB at 4-6, New Process Steel, L.P. v. NLRB, No. 08-1457, slip op. (U.S. June 17, 2010). Regarding the Board's failure to keep pace with dynamic change in the American workplace, see, for example, James J. Brudney, Isolated and Politicized: The NLRB's Uncertain Future, 26 COMP. LAB. L. POL'Y J. 221 (2005); Cynthia L. Estlund, The Ossification of American Labor Law, 102 COLUM. L. REV. 1527, 1533-38 (2002); Wilma Liebman, 
Hence the second proposition: quite apart from what Congress may be able to accomplish, the Labor Board can and should do more to vindicate the Act's purposes and policies and thereby to fulfill its own statutory mission. This Article embraces the second proposition. Its focus is the nature of backpay awards as shaped by the Supreme Court decision in Phelps Dodge Corp. v. NLRB. ${ }^{5}$ Its point of departure is the forceful narrative, written by an experienced Board field attorney, recounting the grim experiences endured by forty-four Orlando hotel workers. ${ }^{6}$ Although the Board determined that the forty-four employees had been discriminatorily discharged in 1996, the workers waited some thirteen years after their firings to receive any back wages. ${ }^{7}$ Many of these men and women - and even their surviving children - endured grueling cross-examination about their interim work histories from the attorney for the lawbreaker employer. Numerous fired workers also had their wage claims reduced at the end of the day for failure to mitigate during some portion of the prolonged post-discharge period.

The circumstances of the Orlando hotel case are extreme, but the extended periods of delay in litigated backpay proceedings are not. Using data for fiscal years 2004-2008 provided by the NLRB, I was able to identify the average time periods from wrongful discharge to receipt of backpay owed for the principal categories of meritorious cases that were resolved through litigation and also for the main categories of meritorious cases that were settled. ${ }^{8}$ The average period for litigated cases is almost five years when the case reaches a Board decision, and over seven years when the case progresses to an appellate court judgment. For settled disputes, the time period is considerably less but hardly trivial given that so many discharges occur during organizing campaigns - nine months for settlements reached without the Board's direct involvement, and more than eighteen months for settlements in which the Board is a participant.

From fiscal years 2004-2008, over 135,000 employees received backpay as victims of employer discrimination, mostly based on unlawful discharges. ${ }^{10}$ These workers were compensated under a private injury-

Decline and Disenchantment: Reflections on the Aging of the National Labor Relations Board, 28 BERKELEY J. EMP. \& LAB. L. 569 (2007).

Phelps Dodge Corp. v. NLRB, 313 U.S. 177 (1941).

See Thomas Brudney, Victims on Trial? A Backpay Case at the NLRB, 5 FIU L. REV. 465

As of February 2010, the discriminatees had not yet received all backpay they are owed.

As explained in Part II, roughly $80 \%$ of meritorious wrongful discharge claims under the Act are settled. Of the litigated cases, about $9 \%$ of discharged claimants receive remedies following a Board decision and another $10 \%$ receive them after an appellate court judgment. Non-meritorious wrongful discharge claims were excluded from these data fields.

9 See infra Part II for presentation and discussion of findings.

10 See infra notes 74 and 91 (summarizing data from Board annual reports). The Board's data field on employees eligible for backpay does not separate discharges from other forms of pay-related 
reparative loss approach, featuring a robust doctrine of mitigation, on which the Board has relied for more than half a century. The reparative loss framework derives from Justice Frankfurter's majority opinion in Phelps Dodge. ${ }^{11}$ The General Counsel over many decades has developed a detailed and elaborate set of backpay and mitigation guidelines, ${ }^{12}$ and recent Board decisions have contributed to the complexity of these calculations. ${ }^{13}$ Backpay determination processes are often cumbersome and time-consuming to apply: they effectively invite employers to reduce and delay monetary recoveries and, not coincidentally, they undermine the remaining employees' interest in pursuing unionization and a collective bargaining relationship.

Working within the existing statutory setting, the Article first asks to what extent the Board has the authority to adjust its approach toward backpay and mitigation. The answer, in short, is more than has previously been understood. The majority opinion in Phelps Dodge relies heavily on the Board's expansive powers to remedy unlawful employer discrimination not only through the "limited function" of repairing private injuries but also by acting "in a public capacity to give effect to" the law's declared public policies, including "safeguarding . . . the right of self-organization.,"14

Invoking the remedial authority found within section 10(c) and embraced in Phelps Dodge, the Article then proposes that the Board act to develop and defend a mandatory minimum backpay award. The proposal calls for a two-tiered approach based on the substantial differences in processing time between successful backpay claims resolved through settlement and claims resolved following litigation. As explained in detail

discrimination such as suspensions or failures to promote. The vast majority of these backpay claimants were unlawfully discharged. See Email from Elizabeth Kilpatrick to author (Feb. 21, 2010) (on file with author). As described in Part II, my analyses focus on the portion of the data fields that assuredly consists only of discharge victims.

11 See Phelps Dodge v. NLRB, 313 U.S. 177, 197-200 (1941).

12 See, e.g., Office of the Gen. Counsel, Nat'l Labor Relations Bd., Casehandling Manual (Part three) COMPLiance ProceEdings $\S \S 10536-10568$ (covering fifty pages), $\S \S 10590$ 10592 (covering six pages); GC Memo 09-01 (2009) (discussing guidelines to litigate what constitutes reasonably diligent job searches and substantially equivalent employment); GC Memo 07-07 (2007) (discussing how to seek compound interest on Board monetary remedies); GC Memo 98-4 (1998) (discussing time frames for pursuing compliance in backpay cases); OM 08-54 (2008) (discussing need for victims to initiate diligent job search in early stages of case processing); OM Memo 08-47 (2008) (discussing time targets for obtaining compliance with Board orders awarding backpay); OM 99-79 (1999) (discussing compensatory damages initiatives under certain circumstances).

13 See, e.g., St. George Warehouse, 351 N.L.R.B. 961 (2007) (requiring employee victims to produce evidence that they searched for particular new jobs); Grosvenor Orlando Assocs., Ltd., 350 N.L.R.B. 1197 (2007) (requiring job search to start after two weeks, regardless of whether employees are still engaged in picketing to get their old jobs back); Oil Capitol Sheet Metal, Inc., 349 N.L.R.B. No. 118, 182 L.R.R.M. (BNA) 1001 (May 31, 2007) (requiring proof that employee victims who are "salts" would have worked for employer for entire backpay period after having been denied a job).

14 Phelps Dodge, 313 U.S. at 193. 
below, employees discharged as a result of unlawful employer discrimination should receive at least one calendar quarter of backpay, to be awarded without regard to net loss or mitigation efforts. Unlawfully discharged employees whose liability or backpay determination is litigated to the Board or appellate court stages should receive at least one year of backpay, again in unreduced form. This mandatory minimum remedy is modeled on a similar longstanding approach adopted by the Board to address employers' failure to bargain in good faith over the effects of plant closings. ${ }^{15}$ The remedy proposed here - like the Board's limited backpay order to remedy bad faith bargaining violations - is meant to vindicate the Act's public policies. In this instance, such a highly visible, mandatory remedy will help to restore and protect the exercise of section seven rights by employees during the many months or years required to investigate and then settle or litigate unlawful discharges.

The Article's principal aim is to explain and justify a proposed mandatory minimum remedy. As part of rethinking aspects of the Board's backpay approach, the Article also suggests that the Board revisit its internal memoranda and guidance materials from a broader perspective by paying more attention to how mitigation issues are addressed under Title VII and the state unemployment insurance system. Such attention, combined with a commitment of additional resources to backpay compliance issues, might enable the Board to diminish the burden on victimized employees, minimize the time and effort required of regional office personnel, and reduce the chances for manipulation or abuse of the system.

Part I examines Phelps Dodge and subsequent Supreme Court decisions, and explains why the Board has considerable leeway to pursue a more proactive remedial approach in backpay cases. Part II presents findings on average delay periods experienced by victims of wrongful discharge, and on how often employees receive less backpay than what the Board determines is due to them. Part II then relies on these findings to propose a two-tiered mandatory minimum award. Part II also briefly raises other possibilities for reducing the burden on employees and the agency in the backpay setting.

15 See Transmarine Navigation Corp., 170 N.L.R.B. 389 (1968); Melody Toyota, 325 N.L.R.B. 846 (1988); Hartzheim Dodge, 354 N.L.R.B. No. 100, 187 L.R.R.M. (BNA) 1105 (Oct. 30, 2009). 


\section{RECALIBRATING THE DOCTRINE OF MITIGATION}

\section{A. The Promise of Phelps Dodge}

The NLRB stance on backpay issues stems to a considerable extent from the Supreme Court decision in Phelps Dodge. It is worth recalling that the majority opinion as a whole represented a triumph for the Board's remedial approach. Justice Frankfurter adopted an expansive view of agency powers under section 10(c) of the NLRA, which directs the Board "to take such affirmative action including reinstatement of employees with or without backpay, as will effectuate the policies of this Act." "16 As part of its mandate to take affirmative action, the Court approved the Board's remedial order that an employer may offer jobs to applicants who had been discriminatorily refused employment even though these individuals had never technically been "employees" of the employer. ${ }^{17}$ Further, the Court endorsed the Board's determination to reinstate discriminatorily discharged employees to their former jobs even if in the interim they had obtained substantially equivalent employment with another employer.

As Justice Frankfurter made abundantly clear, the Board's breadth of remedial authority under section 10 (c) is a function of Congress's concern that the agency always bear in mind "effectuat[ing] the policies of this Act." 19 In determining that the Board could order initial hiring for victims of discrimination, the majority opinion underscored the importance of neutralizing all anti-union employment practices, adding that "[a]ttainment of a great national policy though expert administration in collaboration with limited judicial review must not be confined within narrow canons for equitable relief deemed suitable by chancellors in ordinary private controversies." ${ }^{20}$ Justice Frankfurter was even more emphatic with respect to reinstatement of unlawfully discharged employees who had found equivalent employment during the pendency of litigation. These are individuals whose private injuries have been fully repaired in traditional equity terms. Yet as

1629 U.S.C. $\S 160(\mathrm{c})$ (2006) (emphasis added).

17 See Phelps Dodge, 313 U.S. at 187-89. The employer argued that the phrase "including reinstatement" in section 10(c) reflected Congress's focus on already-hired employees, not job applicants. See id. at 188-89.

18 See id. at 189-93. The definition of "employee" under the Act includes an individual whose work has ceased because of an unfair labor practice "and who has not obtained any other regular and substantially equivalent employment." 29 U.S.C. § 152(3).

19 See Phelps Dodge, 313 U.S. at 188 (invoking the Act's policies to justify providing employment that was wrongfully denied to an applicant); $i d$. at 191 (invoking "the central clue to the Board's powers - effectuation of the policies of the Act - and in that light appraising the relevance of a worker's having obtained 'substantially equivalent employment"').

20 Id. at 188. 
Frankfurter declared, "to deny the Board power to neutralize discrimination merely because workers have obtained compensatory employment would confine 'the policies of this Act' to the correction of private injuries. The Board was not devised for such a limited function." 21 Reinstatement often may not be necessary to repair a discharged worker's loss viewed in ordinary economic terms. The majority insisted, however, that "to limit the significance of discrimination merely to questions of monetary loss to workers would thwart the central purpose of the Act, directed as that is toward the achievement and maintenance of workers'self-organization.",22

The Court's further determination that employees bear some responsibility to mitigate their wage losses must be understood in light of the decision's major theme: construing Board remedies so as to vindicate the Act's public policies. In two paragraphs near the end of the majority opinion, Justice Frankfurter observed that because backpay is intended to compensate for employees' actual lost wages, "it seems fair that deductions should be made not only for actual earnings by the worker but also for losses that he willfully incurred. ${ }^{, 23}$ The Board to this point had not required employees to mitigate, ${ }^{24}$ and at least one circuit court had accepted its position. ${ }^{25}$ Before the Supreme Court, the Board argued that applying the mitigation doctrine would impose an undue administrative burden on the agency. ${ }^{26}$ Justice Frankfurter dismissed the "excessive burdens" argument in a single

21 Id. at 192-93 (emphasis added).

22 Id. at 193 (emphasis added); see also id. ("[The Board] does not exist for the adjudication of private rights; it acts in a public capacity to give effect to the declared public policy of the Act to eliminate and prevent obstructions to interstate commerce by encouraging collective bargaining." (internal citations omitted)). The Act since 1947 has added a right for workers to refrain from self-organization, but the right to organize and engage in collective bargaining free from employer discrimination or retaliation remains a core policy.

23 Id. at 198 (emphasis added).

24 See, e.g., N.Y. Handkerchief Mfg. Co., 16 N.L.R.B. 532, 559-60 (1939); Western Felt Works, 10 N.L.R.B. 407, 447, 449 (1938).

25 See NLRB v. Carlisle Lumber Co., 99 F.2d 533, 538-39 (9th Cir. 1938) (holding that Board is "empowered to restore to the employee both his job and the pay he lost, which would include the time to reinstatement"); see also Aqwilines, Inc. v. NLRB, 87 F.2d 146, 150-51 (5th Cir. 1936) (stating that a back pay order does not award "damages" but constitutes a "public reparation order" designed to further the policy interests set forth in the Act). But cf. Subin v. NLRB, 112 F.2d 326, 331 (3d Cir. 1940) (ordering reinstatement of laid off union supporter but not interim back pay "because by her own testimony her time following the layoff was largely occupied by family duties as a matter of her own choice").

26 See Brief for NLRB at 57, Phelps Dodge, 313 U.S. 177 (Nos. 387, 641) (contending that "[w]e do not believe it was the intent of Congress to preclude effective administration of the Act by requiring the Board to dissipate its energies in time-consuming and speculative inquiries into earnings which were not made but were arguably possible."). 
sentence, asserting that the agency "overestimates administrative difficulties and underestimates its administrative resourcefulness."27

Based on nearly six decades of hindsight, the Board was surely correct in that it had not overestimated the administrative burdens accompanying a mitigation doctrine. The agency's current Compliance Casehandling Manual includes detailed discussion of how Regional Office attorneys should investigate and evaluate mitigation efforts. ${ }^{28}$ This evaluation requires an assessment of whether or to what extent there has been a failure to mitigate based inter alia on inability to secure interim employment; rejecting an offer of interim employment; voluntarily quitting interim employment; being fired from interim employment; unavailability during certain time periods or due to particular circumstances such as illness, injury, pregnancy, military service, or attendance at an educational institution; and withdrawal from the labor market for certain time periods. ${ }^{29}$ Mitigation is often a central feature of backpay settlement discussions or compliance litigation, and here too the Compliance Manual includes specific instructions for regional attorneys. ${ }^{30}$ Apart from the Manual, there are numerous memos from the General Counsel directly, or from the Division of Operations-Management within the office of the General Counsel, that amplify, supersede, and further specify regional office requirements regarding mitigation. ${ }^{31}$ Board attorneys now expend enormous resources on the mitigation issue - when preparing their case, during settlement negotiations, and as part of compliance litigation.

On the other hand, Justice Frankfurter was surely correct when he stated that the Board underestimated its own administrative resourcefulness. Frankfurter made clear that "the Board has a wide discretion to keep the [backpay] matter within reasonable bounds through flexible procedural

27 Phelps Dodge, 313 U.S. at 198. The Board's brief had emphasized the difficulties it anticipated if ordered to administer a mitigation doctrine. See Brief for NLRB, supra note 26, at 56-57 (arguing that especially for cases "involving back pay accruing over a number of years to a large number of men, it would be a tremendous task to ascertain, in each instance, the employment opportunities available in the lines of work which each man was qualified to perform, and to inquire into the intensity and good faith of the efforts made by each to support himself").

28 See generally CASEHANDLING MANUAL, supra note 12, §§ 10558, 10560, 10592

29 See id. $\S$ 10558, 10558.1-.4, 10560, 10560.1-.2, .4-.6, .8.

30 See id. $\$ \$ 10592.6,10648.4,10648.6$.

31 See, e.g., GC Memo 09-01 (2008) (discussing standards for litigating what constitutes a discriminatee's reasonable job search and how to prove there were substantially equivalent available jobs); GC Memos 02-06 (2006), 98-15 (1998), and 88-9 (1988) (setting forth backpay and reinstatement policy where discriminatee's legal status is disputed); OM Memo 09-16 (2008) (discussing what constitutes mitigation by paid union organizers (salts) who experienced job discrimination); OM Memo 08-54 (2008) (discussing time frame for discriminatees to initiate a reasonably diligent search for interim complaint); OM Memo 99-79 (1999) (discussing possibility of supplementing backpay calculations with some form of compensatory damages). 
devices." $" 32$ In this regard, the majority opinion does not require that mitigation be applied in identical fashion to all groups of employees, or that a discriminatee's responsibility to mitigate attaches to every dollar of lost wages. Importantly, the majority opinion nowhere suggests that the Act's public policy regarding unlawful discharges is fully vindicated if discriminatees are made whole for lost wages less what they reasonably could have earned. Even within its two-paragraph discussion of the mitigation issue, the opinion if anything implies just the opposite. Justice Frankfurter reiterates the broad scope of the Board's remedial discretion in backpay situations: making workers whole for their lost wages is only "part of the vindication of the public policy which the Board enforces." its approach to backpay relief, the Board has a "freedom given to it by Congress to attain just results in diverse, complicated situations." 34 And in seeking those just results, the Board "may give appropriate weight to a clearly unjustifiable refusal to take desirable new employment.",

Moreover, as previously discussed, these two paragraphs must be read in the context of the majority opinion as a whole. The Board may give "appropriate" (not conclusive) weight in the backpay setting to a discriminatee's mitigation efforts. A victim's diligence in searching for or accepting interim employment is only one part of the Board's remedial charge, which ultimately involves vindicating the Act's "central purpose: the achievement and maintenance of workers' self-organization.", When designing remedies for intentional employer misconduct in order to advance this central purpose, the Board's powers as expert agency are especially broad: "Because the relation of remedy to policy is peculiarly a matter for administrative competence, courts must . . . guard against the danger of sliding unconsciously from the narrow confines of law into the more spacious domain of policy." ${ }^{37}$

Properly understood, Phelps Dodge leaves the Board with ample authority to develop innovative backpay awards by acting "through flexible procedural devices." meaningful protection to those who were fired for speaking out on behalf of self-organization and also to those not fired but predictably intimidated after seeing what happened to their leaders and spokesmen. Just as failing to reinstate wrongfully discharged union supporters who wish to return

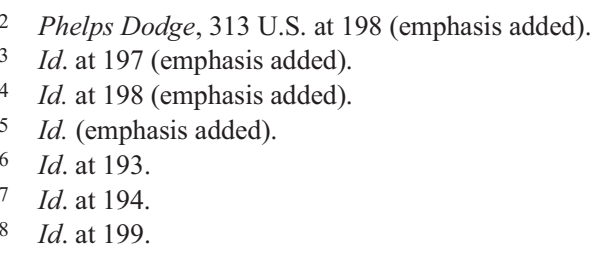


"would sanction a most effective way of defeating the right of selforganization," ${ }^{, 39}$ so too does failing to structure an adequate backpay remedy for those same union supporters.

Some may object that such a close textual reading of Justice Frankfurter's majority opinion places undue weight on words and phrases now six decades old. To be clear, I am not contending the Board may refuse altogether to embark on a mitigation inquiry - the dissenting justices in Phelps Dodge were rebuffed on that argument. ${ }^{40}$ Rather, my contention is that the majority's insistence on a mitigation inquiry still allows for considerable agency flexibility in how that inquiry may be integrated into the mandate of section $10(\mathrm{c})$, which is to effectuate the policies of the Act. ${ }^{41}$

Indeed, an unqualified or absolute approach to mitigation is in tension with the NLRA's core purpose as well as Phelps Dodge's emphasis on Board flexibility and discretion. In discriminatory discharge settings, the Board presumably seeks to ensure that its remedial processes do not operate to undermine or frustrate the strong public policy favoring redress of injuries to section seven rights. These injuries often include the discouragement or intimidation experienced by fired employees and by other union supporters in the workplace when it takes many months or years to receive backpay or reinstatement. Under these circumstances, the Board retains flexibility to accommodate both the employees' responsibility to mitigate their economic losses and the employer's responsibility to provide a meaningful level of recovery to those whose section seven rights

39 Id. at 193.

40 See id. at 206-07 (Murphy, Black, and Douglas, JJ., dissenting in part).

41 A contemporary perspective on Phelps Dodge also gives rise to a somewhat ironic thought experiment. Assuming the issue of requiring mitigation under the NLRA were presented $a b$ initio, it is not at all clear that today's textually oriented Court would rule in favor of such a requirement. The vote on this issue was 4-3 in Phelps Dodge. The three dissenters noted that the Act makes no mention of a need to consider mitigation, and they emphasized that this language gap should hardly be the basis for judicial intervention to limit the remedial powers expressly vested in the Board under section 10(c). When comparing the NLRA remedial provision with the remedial language in Title VII of the Civil Rights Act, or in the Americans with Disabilities Act, it is apparent that Congress knows how to include specific text requiring that discriminatees attempt to engage in mitigation. See 42 U.S.C. $§ 2000 \mathrm{e}-5(\mathrm{~g})$ (2006) (Title VII) (stating that "interim earnings or amounts earnable with reasonable diligence by the person or persons discriminated against shall operate to reduce back pay otherwise allowable"); 42 U.S.C. $\S 12117$ (a) (ADA) (incorporating remedies set forth in $\S 2000 \mathrm{e}-5$ for ADA use). And the modern Court has famously relied on close textual analysis along with language canons to conclude that when Congress omits a remedial element it has provided for in other statutes, the omission should be taken seriously. See, e.g., Mertens v. Hewitt Assocs., 508 U.S. 248, 255-58 (1993) (holding that monetary damages are not awardable as "appropriate equitable relief" under $\S 502$ of ERISA); United States v. Burke, 504 U.S. 229, 238-39 (1992) (holding that "other [appropriate] equitable relief" under Title VII precluded awards of compensatory or punitive damages prior to language change in 1991 amendments); W. Va. Univ. Hosps. v. Casey, 499 U.S. 83, 88-92 (1991) (Scalia, J.) (holding that expert fees are not awardable as part of a "reasonable attorney's fee" under 42 U.S.C. $§ 1988$ ). 
have been violated. If the duty to mitigate applies without qualification from the first dollar of backpay forward, then the costs associated with protecting section seven rights during organizing campaigns and collective bargaining drives fall too heavily on the shoulders of victimized employees. In order to address the daunting effects of discriminatory discharges on employees who remain in the workplace and employees who have been wrongfully terminated, a guaranteed minimum level of monetary recovery seems appropriate.

In sum, under a fair reading of Phelps Dodge, the Board has not yet done enough to justify Justice Frankfurter's faith in its administrative resourcefulness and in particular its capacity to develop flexible procedural devices. The majority's determination that the Board give "appropriate weight" to an employee's failure to mitigate should be combined with the majority's repeated declaration that all remedies - including backpay must effectuate the policies of the Act. The Board has periodically expressed an awareness of its dormant remedial authority regarding backpay. The General Counsel recognized that backpay orders should do more than repair out-of-pocket monetary losses: they "also effectuate the purposes of the Act by discouraging [employers] from further unfair labor practices and by assuring discriminatees that the Government is protecting their rights under the Act." ${ }^{, 2}$ One important way for backpay orders to serve these ends is through a mandatory minimum award of one or more calendar quarters, an approach that can then complement employees' obligation to mitigate.

\section{B. The Court's Subsequent Treatment of Phelps Dodge}

Before examining the contours for a mandatory minimum backpay award, it is important to understand how the Court has developed its Phelps Dodge approach to backpay and mitigation in later decisions. The Court has cited Phelps Dodge in ninety subsequent cases, and both its expansive view of the Board's overall remedial authority and the need to consider discriminatee efforts at mitigation remain good law. At the same time, many citations to the Phelps Dodge majority relate to non-backpay aspects of the decision or are cursory in nature. Of the handful of Supreme Court cases that discuss the Phelps Dodge remedial approach in any depth, two decisions warrant attention in this setting.

42 CASEhandling Manual, supra note 12, § 10536.1; see also OM Memo 99-79 at 1 ((emphasizing Board's role under $\S 10(\mathrm{c})$ to include dissipation of the employer's coercive conduct as part of its remedial approach). 
The most important subsequent Court decision is NLRB v. Seven-Up Bottling Co., ${ }^{43}$ decided in 1953. In Seven-Up Bottling, the only issue before the Court was the Board's method of computing backpay for acknowledged victims of employer discrimination. Until 1950, the Board had calculated backpay awards based on the entire period from discharge to offer of reinstatement, subject to deductions for interim earnings or losses willfully incurred over that period. In an attempt better to effectuate the policies of the Act, the Board in a 1950 decision had modified its backpay approach of fifteen years so as to calculate lost wages based on each separate calendar quarter. $^{44}$ Writing for the Court once again, Justice Frankfurter upheld the Board's new framework; in doing so, he rejected the company's argument that a blanket rule applying the quarterly calculation method exceeded the Board's remedial powers. ${ }^{45}$

Significantly, the Board had switched to calendar quarters in 1950 based on its conception of what would best remedy the effects of employer discrimination apart from providing for the amounts of backpay actually owed. During the usually-prolonged period from unlawful discharge to offer of reinstatement, employees may at times secure interim jobs that pay more than the jobs from which they were fired. Under a calculation formula based on the entire backpay period, employers may therefore have an incentive to delay reinstatement in order to reduce or even eliminate their cumulative backpay liability. ${ }^{46}$ Additionally, employees who have begun earning higher wages many months after discharge often feel compelled to waive their right to reinstatement in order to toll the backpay period and prevent the continuing reduction of monies due to them from the initial months or years when they earned far less. ${ }^{47}$ Both of these incentives adversely affect the likelihood of reinstatement, and the Board had determined that this companion remedy is "one of the most effective measures . . . for expunging the effects of unfair labor practices and maintaining industrial peace." ${ }^{48}$

43 NLRB v. Seven-Up Bottling Co., 344 U.S. 344 (1953).

44 See F.W. Woolworth Co., 90 N.L.R.B. 289 (1950), discussed in Seven-Up Bottling, 344 U.S. at $345,347-48$

45 See 344 U.S. at $345-49$.

46 See F.W. Woolworth Co., 90 N.L.R.B. at 291-92.

47 See id. at 292. For instance, assume an employee earned \$20,000 annually when discharged, then she earned $\$ 10,000$ during her first year after the firing (based on a diligent job search) and $\$ 30,000$ on a temporary job during her second year. Under the pre-Woolworth calculation formula, her employer has an incentive to delay any reinstatement offer through extended litigation and appeals - if the period before reinstatement lasts two years, all backpay liability will have been eliminated. The employee, on the other hand, may feel compelled to waive her right to reinstatement shortly after she secures the higher-paying temporary job, in order to preserve as much backpay award as possible.

48 Id. 
A number of key points emerge from the majority opinion endorsing the Board's determination to modify substantially its backpay approach. First, Justice Frankfurter reaffirms the limited role that employee efforts to mitigate should occupy in the Board's backpay arsenal. Although the Board "must have regard for considerations governing the mitigation of damages," its remedial powers under section 10(c) remain very broad. A backpay order should stand "unless it can be shown that the order is a patent attempt to achieve ends other than those which can fairly be said to effectuate the policies of the Act." ${ }^{, 9}$

Second, and relatedly, the Court declared that the agency's major remedial change was distinctly policy-driven. The Board had invoked its cumulative experience over many years to promote more effectively the Act's basic purposes; it determined that a robust reinstatement option was needed to eliminate as much as possible the ongoing effects of employer discrimination. $^{50}$ The Court made clear it had no business weighing the Board's policy considerations or any counterveiling arguments, nor did the Board need to support its policy judgments with an empirical analysis of all relevant factors. ${ }^{51}$ Rather, "the Board's conclusions may express an intuition of experience which outruns analysis and sums up many unnamed and tangled impressions . . . and they are none the worse for it.",52

Third, the quarterly calculation method endorsed by the majority was a class-based or blanket approach. Justice Douglas in dissent agreed that the Board has the power to adopt a new calculation formula, but he objected to its rule-like application in all cases. His particular concern was that for a discriminatory employer whose business and wage payments fluctuate from one quarter to the next, discharged employees who secure an interim job with steady wages will probably receive backpay awards in excess of what they would have received had they not been discharged. ${ }^{53}$ The majority understood this result, but concluded that the importance of expunging discriminatory effects justified some employees receiving more backpay than they would have earned had they worked their "regular job." In addition, as Justice Minton pointed out in his separate dissent, the Board's blanket calendar-quarter approach also meant that in some instances "the employer must pay more than he would have had to pay if he had had the employee's

49 Seven-Up Bottling, 344 U.S. at 346-47 (quoting Va. Elec. \& Power Co. v. NLRB, 319 U.S. 533, 540 (1943)).

$50 \quad$ See id. at 347.

51 See id. at 348.

52 Id. (internal citations omitted); see also id. at 349 (emphasizing, per Phelps Dodge, that "the relation of remedy to policy is peculiarly a matter for administrative competence").

53 See id. at 352-53. 
services during the period."54 Once again, the Court's conclusion indicates that the Board may decide to effectuate the purposes of the Act in a backpay setting by prescribing a monetary award that exceeds the overall net effects, after accounting for interim employment and a reasonably diligent job search.

In the years since Seven-Up Bottling, the Court has continued to refer to Phelps Dodge, recognizing the Board's considerable discretion when it commands affirmative action under the remedial scope of section 10(c). In a 1961 decision, the Court emphasized the Board's broad authority to order affirmative relief "as a means of removing or avoiding the consequences of violation where those consequences are of a kind to thwart the purposes of the Act." ${ }^{, 55}$ Fourteen years later, the Court in establishing the scope of backpay relief under Title VII noted that the civil rights statute's make-whole purpose derived from section 10(c) of the NLRA, under which making workers whole for monetary losses they suffered due to unfair labor practices was "part of the vindication of the [Act's] public policy.,"56

Apart from Seven-Up Bottling, the other post-Phelps Dodge decision that deserves extended attention in this context is the 1984 case, Sure-Tan Inc. $v$. $N L R B .^{57}$ At first glance, Sure-Tan would appear to limit substantially what the Board is able to accomplish through mandatory minimum backpay remedies. The case involved whether undocumented immigrants who were victims of employer discrimination could receive a six-month mandatory backpay award. Writing for a 5-4 majority, Justice O'Connor concluded that the Board lacked authority to order this relief. ${ }^{58}$ Upon close reading, however, it becomes clear that for several reasons the Sure-Tan decision comports with the Phelps Dodge approach as explained earlier in this Part.

54 Id. at 355 (Justice Minton was joined in his dissent by Chief Justice Stone.).

55 Local 60, United Bhd. of Carpenters v. NLRB, 365 U.S. 651, 655 (1961) (emphasis added) (relying on Phelps Dodge). The Court in Local 60 held that the Board had exceeded its broad powers because the Board's remedy against the union - a compelled refund of dues and fees collected from employee members - did not involve removing any "consequences of violation" and was therefore punitive rather than remedial in nature. See id. at 655-56.

56 Albemarle Paper Co. v. Moody, 422 U.S. 405, 419 (1975) (emphasis added) (relying on Phelps Dodge); see also NLRB v. Truck Drivers Local Union No. 449, 353 U.S. 87, 96 n.28 (1957) (relying on Phelps Dodge to emphasize that because Congress knew it could not "define the whole gamut of remedies to effectuate [the Act's] policies in an infinite variety of specific situations," it left "the adaptation of means to end to the empiric process of administration" - committed to the Board with only limited judicial review (internal citations omitted)).

57 Sure-Tan, Inc. v. NLRB, 467 U.S. 883 (1984).

58 See id. at 899-901. The Court reversed the appellate court, which had expanded the Board order by providing for minimum six months backpay. See id. at 899 . Because the Board fully acquiesced in the appellate court remedy, the Supreme Court considered whether the mandatory minimum backpay award was "within the Board's own powers" on the instant record and concluded that it was not. Id. at 899 n.11, 901 . 
First, Justice O'Connor's majority opinion did not object to the concept of a mandatory minimum backpay award. Rather, the Court rejected the appellate court's mandate of six months backpay because it was based on a wholly speculative assumption - that six months was the minimum period discriminatees might reasonably have been employed before being apprehended by the Immigration and Naturalization Service. ${ }^{59}$ The failure to support an empirical assumption as to how long discriminatees who are also undocumented immigrants would have gone undetected under a superseding national enforcement program administrated by a separate agency does not speak to other empirical or policy justifications for mandatory minimum backpay relief. In particular, the Court's reasoning does not address the prospect of providing minimum backpay awards to effectuate the policies of section 10 (c) by vindicating rights to organize for terminated and surviving employees in general, or by deterring employers from committing unlawful discharges that undermine these rights.

In a related vein, the Sure-Tan majority invoked Phelps Dodge when recognizing the basic legitimacy of backpay relief "as a means to restore the situation as nearly as possible" to what it would have been but for the employer's discriminatory conduct. ${ }^{60}$ This sensitivity to the importance of restoring the larger situation - not simply the net monetary losses - is consistent with the concept of a mandatory minimum award that would remove intimidation and restore confidence for both fired and surviving employees.

Admittedly, the Court in Sure-Tan envisions a backpay remedy that "expunge[s] only the actual, and not merely the speculative, consequences of the unfair labor practices." "61 This, however, is where - unlike the record in Sure-Tan - the Board can draw on ample support that discriminatory firings and subsequent delays in the remediation process have had an enormously intimidating impact on core protected activities under the Act. The Board is able to address these actual consequences of violation by referencing its own cumulative expertise in investigating and adjudicating hundreds of thousands of unlawful discharge cases - its "intuition of

59 See id. at 899 (quoting from lower court's "six months is a reasonable assumption" analysis); $i d$. at 900 (observing that section 10(c) confers broad discretion but proposed remedy must "be tailored to the unfair labor practice it is intended to address"); $i d$. at 901 (concluding that six-month minimum backpay award "in the total absence of record evidence . . constitutes pure speculation and does not comport with the general reparative policies of the NLRA"); see also id. at 909 (Brennan, J., dissenting) (defending appellate court's six-month award as resting on a lower court estimate that includes a sufficient degree of precision).

60 Id. at 900 (emphasis added; internal citations omitted).

61 Id. (citing by analogy to Phelps Dodge). 
experience which . . . sums up many unnamed and tangled impressions." ${ }^{, 62}$ Courts have long respected the Board's authoritative discretion to take remedial action based on its conclusions as to how reasonable employees objectively would tend to respond to unlawful employer discrimination or coercion. $^{6}$

In addition to its intuition of experience, the Board can refer to an array of government and scholarly studies that confirm beyond doubt the distinctly adverse effects on organizing campaigns of unlawful firings and extended delays in the resolution of meritorious claims. ${ }^{64}$ Pursuant to Seven-Up Bottling's approval of Board adjustments in formulating backpay awards policy, the Board should invoke these studies as further justification to establish a backpay mandatory minimum award. Part II below addresses how to tailor the minimum award period based on the nature and magnitude of delays associated with receipt of backpay awards.

A final observation regarding Sure-Tan involves Justice O'Connor's statement in a footnote that "to our knowledge, the Board itself has never

62 NLRB v. Seven-Up Bottling Co., 344 U.S. 344, 348 (1953).

63 See, e.g., Golden State Bottling Co. v. NLRB, 414 U.S. 168, 184-85 (1973) (invoking Board reliance on its experience with respect to likely impact of unremedied unfair labor practices on a successor's workforce); Phelps Dodge v. NLRB, 313 U.S. 177, 193 (1941) (invoking Board knowledge of industrial affairs in recognizing likely effects of refusals to reinstate on the organizing rights of remaining employees); Ne. Land Servs. Ltd. v. NLRB, 560 F.3d 36, 43 (1 st Cir. 2009) (relying on Board test that employer's workplace rule is unlawful if "employees would reasonably construe the language [of the rule] to prohibit Section 7 activity").

64 For evidence of intimidating consequences from unlawful discharges, see for example General accounting Office, Concerns Regarding Impact of Employee Charges Against EMPLOYERS FOR UNFAIR LABOR PRACTICES (1982) (reporting diminished success for unions in campaigns during which employer discrimination occurred); William T. Dickens, The Effect of Company Campaigns on Certification Elections: Law \& Reality Once Again, 36 InduS. \& LAB. REL. REV. 560, 568-69 (1983) (reporting significant reduction in union support when employer takes action against prounion employees); Morris M. Kleiner, Intensity of Management Resistance: Understanding the Decline of Unionization in the Private Sector, 22 J. LAB. RES. 519, 528-30 (2001) (same). In addition, see Richard B. FREEMAN \& JAMES L. MEdofF, WhAT Do Unions Do? 234-36 (1984) (summarizing findings from six studies); Kate L. Bronfenbrenner, Employer Behavior in Certification Elections and First-Contract Campaigns: Implications for Labor Law Reform, in RESTORING THE PROMISE OF AMERICAN LABOR LAW 81 (Sheldon Friedman et al. eds. 1994) (describing how studies actually underestimate negative impact from firings because they do not include the many campaigns that collapse before an election once the employer has fired key union supporters); see also id. at 78-79 (reporting that for 261 union elections occurring in 1986 and 1987, win rate declines from 50\% if election is held within sixty days of petition to $31 \%$ if election is held 61-180 days after petition, and observing that delays "give employers a longer time period in which to campaign aggressively"); Myron Roomkin \& Richard N. Block, Case Processing Time and the Outcome of Representation Elections: Some Empirical Evidence, 1981 U. ILL. L. REV. 75, 76, 88 -89 (reporting that for over 45,000 union elections studied, win rate decreases steadily from $50 \%$ (if election is held less than one month after petition is filed) to $30 \%$ (if election occurs four to seven months after petition is filed), and suggesting that "delay gives employers added opportunity to dissuade employees and increases the likelihood of turnover in the workforce" thereby undermining unions' efforts to retain employee support). 
attempted to impose a minimum backpay award that the employer must pay regardless of the actual evidence as to such issues as an employee's availability for work or his efforts to secure comparable interim employment." ${ }^{, 65}$ In fact, the Board by this time had established just such a mandatory minimum award in an effort to address an employer's intentional failure to bargain in violation of the Act. In Transmarine Navigation Corp., ${ }^{66}$ the Board held that when an employer refuses to bargain over the effects of a plant closing, the standard remedy includes a requirement that the employer provide a minimum of two weeks backpay to all affected employees. Although the Court was evidently unaware of this standard remedy, the Transmarine backpay award had been endorsed by at least one circuit when Sure-Tan was decided. ${ }^{67}$ Since 1986, it has been reaffirmed regularly by the Board, ${ }^{68}$ and accepted by every circuit to consider its propriety. ${ }^{69}$

The rationale for the Board's minimum two-week backpay award derives from the need to effectuate policies under section 10(c). An employer's unlawful failure to bargain over effects denies the employees the opportunity to engage in the protected activity of bargaining at a time before the plant closing when such activity "would have been meaningful.," Given the time delays involved in establishing employer liability, and the consequent impossibility of returning to the status quo ante, the Board's mandatory minimum award reflects "the principle that the wrongdoer, rather than the victims of his wrongdoing, should bear the consequences of his unlawful conduct." "71 As elaborated by the appellate courts, the purpose of the limited backpay requirement "is not to punish, but to create an incentive for the Company to bargain in good faith [which] comports with the primary objective of the Act.,"72 Thus, the aim of the Board's innovative Transmarine remedy is two-fold. It seeks to make employees whole for their losses, at least to a degree. But "more importantly,

65 Sure-Tan, 467 U.S. at 901 n.11 (emphasis added).

66 Transmarine Navigation Corp., 170 N.L.R.B. 389 (1968).

67 See Yorke v. NLRB, 709 F.2d 1138, 1145 (7th Cir. 1983).

68 See, e.g., Hartzheim Dodge, Inc., 354 N.L.R.B. No. 100, 187 L.R.R.M. (BNA) 1105 (Oct. 30, 2009); Melody Toyota, 325 N.L.R.B. 846 (1988). See generally CASEHANDLING MANUAL, supra note $12, \S 10528.7$.

69 See, e.g., Int'l Bhd. of Elec. Workers, Local 21 v. NLRB, 563 F.3d 418, 423-24 (9th Cir. 2009); NLRB v. Pan Am. Grain Co., 432 F.3d 69, $72-73$ (1st Cir. 2005); NLRB v. Waymouth Farms, Inc., 172 F.3d 598, 600 (8th Cir. 1999); see also NLRB v. Emsing's Supermarket, Inc., 872 F.2d 1279, 1290-91 (7th Cir. 1989).

70 Transmarine, 170 N.L.R.B. at 389.

71 Id. (emphasis added) (citing to Phelps Dodge).

72 Yorke, 709 F.2d at 1145. 
[it is] designed to restore at least some economic inducement for an employer to bargain as the law requires." 73

In sum, Phelps Dodge and its progeny leave the Board with freedom to develop remedies that will effectuate the policies of the Act. And Transmarine reflects the Board's ability to construct a mandatory minimum backpay remedy appropriately focused on furthering those policies without regard to the victimized employees' efforts at mitigation. At the same time, Sure-Tan's caveat that such remedies should be tied to actual rather than speculative consequences of violation provides an apt transition to considering backpay relief in response to discriminatory firings.

\section{INCORPORATING A MANDATORY MINIMUM AWARD INTO BACKPAY RELIEF}

In order to justify a proposal for mandatory minimum backpay awards in wrongful discharge cases, it is necessary to explain what actually happens when the NLRB attempts to secure disbursement of backpay as a remedial matter. The Labor Board collects a substantial amount of information with respect to remedial action undertaken in unfair labor practice (ULP) proceedings. Table 4 in the Board's Annual Report discloses the number of employees receiving backpay in cases closed each fiscal year. ${ }^{74}$ For fiscal years 2004-2008, over 135,000 employees received backpay from their former or current employers as victims of unlawful discrimination. ${ }^{75}$ I was interested in more detailed data for this 2004-08 period regarding delays in payment to unlawfully fired employees. I also wanted to explore whether these discharge victims receive the full backpay amounts the Board concludes are owed by their employers, and if not what is the extent of the shortfall.

73 Emsing's Supermarket, 872 F.2d at 1291.

74 See, e.g., 73 NLRB ANN. REP. tbl.4 (2008) (reporting that 17,204 employees received backpay from employers in FY 2008); 71 NLRB ANN. REP. tbl.4 (2006) (reporting that 26,824 employees received backpay from employers in FY 2006); 69 NLRB ANN. REP. tbl. 4 (2004) (reporting that 30,784 employees received backpay from employers in FY 2004). In addition to lost wages, the Board's net backpay remedy may also include nonwage benefits of employment such as expenses due to the loss of medical insurance, or lost contributions to pension funds. See CASEHANDLING MANUAL, supra note 12, $\S 10544$. The instant mandatory minimum proposal focuses only on lost wages.

75 During the same five year period, some 1900 employees received backpay from unions for unlawful practices. See infra note 131. Thus, employers' discriminatory conduct accounts for $99 \%$ of the employees receiving backpay relief. Because the raw number and proportion of backpay recipients is so overwhelmingly tilted toward unlawful conduct by employers, they are the focus of this proposal. However, as noted infra Part II.C.2. I suggest that some version of the proposal might apply to union wrongdoers as well. 
In this Part, I first discuss the process of assembling a database, including background on the Board's approach to classifying backpay cases. I then present my findings, focused primarily on average periods of delay in receiving backpay and on the proportion of employees who receive less than what they are owed. Next, I explain how these findings support a twotiered mandatory minimum backpay award that distinguishes between settled and litigated cases. As part of the discussion, I consider concerns that might be raised regarding my proposal.

\section{A. Assembling a Database}

The Board collects and records time-specific developments in meritorious ULP cases that involve backpay and/or reinstatement, starting from the date a charge was filed. For each charge that results in the Board prevailing (in whole or in part), additional data include the date a complaint issued plus dates for all decisions by an Administrative Law Judge (ALJ), the Board, or a court of appeals. Each successfully resolved charge also includes an entry for the date a closed case report (CCR) is filed.

The CCR is typically completed by the Regional Office trial attorney or board agent who has primary responsibility for overseeing the case, or by the Regional Compliance Officer. It is not filed until remedies have actually been received by the affected employees. These remedies include inter alia posting of notices, implementation of reinstatement, and disbursement of backpay. Monetary relief is almost invariably the most contentious item, taking the longest to resolve, and the General Counsel's Compliance Manual is explicit about the CCR being held in abeyance until disbursement of backpay. ${ }^{76}$ Based on discussion with staff from the Division of Operations-Management, I determined to use the CCR date as the presumptive date on which employees received their backpay. ${ }^{77}$

\section{Resolving Meritorious Backpay Claims:}

Six Approaches

Although all successful backpay claims have a charge and a CCR, there is considerable variation regarding intermediate stages. In the backpay setting, the Board records six distinct approaches to resolving

76 See, e.g., Casehandling Manual, supra note 12, § 10594.11. See generally id. $\S 10576.2$ (describing standard procedures for disbursement of backpay); id. § 10592.12 (describing procedures for accepting backpay in installment payments).

77 With respect to non-Board adjustments, defined below, the Regional Office may file a CCR after approving withdrawal of a potentially meritorious charge, conditioned on the charged party fulfilling its privately negotiated obligations. See CASEHANDLING Manual, supra note 12, $\S \S 10120.5$, 10142.3 ; see also infra note 79. 
meritorious cases. Three resolutions are by means of negotiated agreement: non-Board adjustments, informal Board settlements, and formal Board settlements. The other three involve compliance with an adjudicated decision: by an ALJ, by the Board, or by an appellate court. In summarizing each of the six approaches, I also explain why only four of the six are of consequence for my purposes.

A non-Board adjustment is a private agreement between the employer and affected employees or their union. It is usually reached before an adjudicated determination on the merits, although it may occasionally be negotiated following a Board or ALJ decision. Because the General Counsel is not a party to non-Board adjustments, the agency is not in a position to enforce them. ${ }^{79}$ At the same time, the Regional Office does process the charge and investigate the merits; accordingly, the charging party may withdraw the case only if the Regional Office agrees that the adjustment is not repugnant to public policy. The Board has adopted an informal $80 \%$ rule with respect to backpay cases. If a proposed settlement provides that employees will receive less than $80 \%$ of what is due and owed to them, the Regional Office may approve the non-Board adjustment (or sign off on an informal Board settlement, as explained below) only after submitting it to Washington. ${ }^{80}$ For the five-year period being examined, non-Board adjustments covered about $43 \%$ of all successful charges involving backpay, and roughly $33 \%$ of all employees receiving backpay.

An informal Board settlement is an agreement approved by the General Counsel. Typically, the Regional Office has completed a merits determination before issuing a complaint; the Office communicates this to the parties and allows them a chance to enter into an agreement. ${ }^{81}$ The informal settlement is so named because Board members are not formal parties to the agreement. However, the General Counsel is a party (usually

78 The description of these six approaches - contained in the following six paragraphs of text - is based on conversations with Operations Management and Regional Office personnel, and review of the General Counsel Compliance Casehandling Manual. The proportion of charges and affected employees covered under each approach was gleaned from data furnished by the Division of OperationsManagement, with invaluable analysis and insights from my research assistant, Aaron Cornell, Moritz College of Law, Class of 2011.

79 If the settlement is breached, the Board may be able to reopen the case to address the particular circumstances. See CASEHANDLING MANUAL, supra note 12, § 10123.3.

80 See CASEhandling ManuaL, supra note 12 , $\S \S 10592.4,11752$. In applying this $80 \%$ rule, what the Regional Office calculates as due and owing takes account of both interim earnings and the duty to mitigate.

81 The same $80 \%$ rule applies as was true for non-Board adjustments. This $80 \%$ rule is not supposed to trigger an automatic reduction to $80 \%$ of the backpay amounts due. In practice, however, many private attorneys believe the rule signals a willingness to accept up to $20 \%$ reductions, and this can make it more difficult for the Regional Office to secure $100 \%$ of the amount owed. 
through the Regional Office), and accordingly the agency may be in a position to enforce the agreement if slippage occurs. Still, there is no court approval of an informal settlement so enforcement through contempt action is not available. From 2004 to 2008, informal settlements covered roughly $41 \%$ of all successful backpay charges and about $47 \%$ of affected employees.

Together these first two types of settlements encompass over $80 \%$ of charges and $80 \%$ of affected employees. ${ }^{82}$ The third settlement approach, formal Board settlement, involves a court-approved agreement with Board members as actual parties. Because a court is involved, the settlement is enforceable through a contempt action. These formal settlements are exceedingly rare; they cover less than one percent of charges and of affected employees during the five year period.

Turning to the three distinct litigation approaches, compliance with ALJ decision is by far the rarest, covering well under one percent of charges and affected employees. Although a substantial number of ALJ decisions address employers' backpay liability and some address disputes over the amount owed, it is extremely unlikely that the case will end at the ALJ level. Many of these litigated cases are appealed to the Board; even when the ALJ result is not contested, it is almost always formally approved or adopted by the Board in a period of weeks or months. ${ }^{83}$

Compliance with a Board decision occurs when the employer implements the backpay and reinstatement terms contained in the Board's decision, including terms incorporated from the ALJ decision. The CCR date may not closely follow the Board decision date if for whatever reason it takes time for payments to be disbursed. From 2004 to 2008, compliance with Board decisions covered about $8 \%$ of charges and $9 \%$ of affected employees. $^{84}$

Finally, compliance with a court judgment refers to employer implementation of backpay and reinstatement terms as resolved by a reviewing court of appeals or, on rare occasions, the Supreme Court. The reviewing court may reduce or otherwise modify Board-ordered remedies including the amount of backpay owed. This category of litigated resolutions covered

\footnotetext{
82 Exact percentages are $84 \%$ of successful backpay charges $(43+41)$ and $80 \%$ of affected employees $(33+47)$.

83 See generally NLRB Rules and Regulations, 29 C.F.R. § 101.11 (2009).

84 Board decisions under this heading are predominantly unfair labor practice decisions, but they also include compliance decisions addressing contested backpay amounts. Of the 316 charges giving rise to Board decisions in this five-year period, only twenty-four (7.6\%) resulted in compliance decisions.
} 
about $7 \%$ of charges and $10 \%$ of affected employees. ${ }^{85}$ Thus, the two main litigation categories encompass $15 \%$ of charges and roughly $20 \%$ of affected employees during our five-year period.

As previously noted, the CCR date follows behind each of these six types of charge resolution. The report may be filed only a few weeks or months after the settlement or adjudication, but the process sometimes takes years. There may be negotiations or contests over the reasonableness of the employees' efforts to mitigate, or over an employer's asserted inability to make timely payments, the implications of an employer's bankrupt or debtor status, or an employer's bad faith intransigence. On occasion, the Board may be a contributing source of delay due to inadequate communication between the Regional Office and Washington or to workload challenges at the Regional Office level. In this regard, although the General Counsel has made the conduct of prompt elections a top goal over the past ten to fifteen years, completion of backpay proceedings is a lower agency priority. ${ }^{86}$

\section{Separating Backpay Claims that Involve Only Discharged Employees}

The previous calculations - allocating closed meritorious cases among the Board's six categories - were based on the entire universe of meritorious backpay claims brought under sections $8(a)(3)$ or $8(a)(1) .^{87}$ The Board's data retrieval does not distinguish backpay claims involving discharged employees from claims awarding backpay to other victims of discrimination - such as employees who are temporarily suspended, who are denied a promotion, or who experience a wage reduction. With assistance from the Operations-Management Division, I was able to identify all backpay cases in which employees also were reinstated: this group by definition consists only of discharge victims. The group of other backpay recipients - for which charge data regarding reinstatements disclosed either a blank entry or entry of a "zero" - includes a substantial number of discharge victims who did not seek or choose to accept reinstatement, or who were not offered it. But this latter group is a hybrid - it also includes indi-

85 Court judgments under this heading involved Board compliance proceedings following the unfair labor practice decision more frequently than was the case in the "Board decisions" heading. See supra note 84 . Of the 274 charges giving rise to court judgments, sixty-three (23\%) resulted in compliance decisions.

86 See, e.g., GC Memo 98-4 (1998); GC Memo 96-2 (1996) (identifying backpay compliance cases as having a lower priority, and a longer completion period, than cases involving conduct of elections, withdrawal of recognition, surface bargaining, successorship, and other "more central" issues).

87 The universe of cases selected involved only section 8(a)(3) discharge and backpay claims that did not also involve section 8(a)(5) allegations. See Kilpatrick E-mail, supra note 10. 
viduals whose backpay stems from a less drastic change in employment status such as a suspension or non-promotion.

In presenting findings on the average time periods before receiving backpay and the proportion of successful claimants who received less than what the Board determined was due to them, I focus on the group comprised exclusively of discharged employees. When union activists or supporters endure the "capital punishment" of job termination, their private injuries give rise to the public policy consequences that were recognized in Phelps Dodge but that have been less than fully addressed by the Board's reparative stance on backpay. By contrast, short-term job losses and pay reductions are far less prevalent forms of employer discrimination; they also do not implicate the Act's core policies to nearly the same extent. As it happens, differences between the "pure discharge" group and the hybrid group are at times not all that substantial, and I report some results for the hybrid group as well. ${ }^{88}$

\section{Estimating the Period from Discharge to Filing of Charge}

Board data is collected and organized from the filing of a charge forward. The period for computing backpay, however, runs from the date of discharge forward. Discharge victims must file a charge within six months of being fired, ${ }^{89}$ but I wanted to be more precise about the average time from discharge to charge in our five-year period.

My research assistant, Aaron Cornell, reviewed every published Board opinion involving an unlawful discharge that appeared in FY $2006 .^{90}$ I chose FY 2006 because it was the mid-point for the five-year period and also because it was representative in annual terms of the number of employees receiving backpay from employers during the five-year period. ${ }^{91}$ The average period from discharge to charge for these FY 2006 decisions was thirty-one days. In the findings below, I added the thirty-one-day

88 This hybrid group is larger in numerical terms than the group of charges involving "pure discharge" victims - but it bears repeating that many backpay claims in the hybrid group involve discharges as well.

89 See 29 U.S.C. $§ 160$ (b) (2006) (specifying that Board may not issue a complaint based on conduct occurring more than six months prior to the filing and service of the charge).

90 This effort entailed reviewing every decision appearing in all or parts of four volumes of NLRB Decisions (345 N.L.R.B. - 348 N.L.R.B.) identifying cases involving successful discharge claims, and then noting the dates of discharge and charge. There were ninety-two published decisions involving unlawful discharges during the twelve-month period. For decisions that omitted either date of charge or date of discharge, the OM Division provided almost all missing information.

91 See supra note 74 (meritorious backpay claims from employers for FY 2006 encompassed 26,824 employees, roughly one-fifth the total of 135,729 employees over the five-year period). 
figure to each of the average periods from charge to disbursement of backpay. ${ }^{92}$

\section{Caveats Regarding the Dataset}

Before reporting on results in some detail, I want to emphasize that these are preliminary findings. In collecting and coding the data, I have relied on the good faith efforts of dedicated professionals at the NLRB. ${ }^{93}$ During the course of data-gathering, I discovered occasional errors in data entry as well as a few puzzling data omissions. Any systemic attempt at entering and coding data must of course recognize the risk of human error. The instant effort was conducted in a compressed period of weeks and involved coding the available data in ways that differ from the Board's regular approach. I am extremely grateful to Board personnel for their efficiency, skill, and patience in responding to my requests on top of their ordinary duties and pressures. I am confident as to our findings, but I also am confident that the results reported here would benefit from further expansion and analysis. ${ }^{94}$

One other caveat involves my decision to report findings based on averages over the most recent five-year period. This approach reflects a belief that any proposal for reform of current practice ought to be based on the best available current data. At the same time, the Board's system for resolving meritorious backpay claims has developed over decades. The discrete 2004-08 period is not necessarily representative of the past ten or twenty years, much less the longer time frame. Insofar as my findings and the related proposal are deemed useful, the Board may wish to engage in more extensive data collection and analysis to justify or modify the recommended approach.

\section{B. Findings}

I begin by reporting the average time period between date of discharge and receipt of backpay for the four types of resolution that together consti-

92 This thirty-one day figure stems only from cases that involve Board decisions; no comparable calculation was made for the meritorious backpay claims that are settled. Such a calculation would require reviewing thousands of files addressing these unreported settlements, a task well beyond my resources. Moreover, there is no reason to believe that the number of days victims take to file a charge for unlawful firings is materially different whether the charge is subsequently settled or litigated - that disposition is unknown and probably unknowable at the time the charge is filed.

93 The one exception is data for estimating the period from discharge to charge, which was initially collected and analyzed by my research assistant, Aaron Cornell. See supra note 90 and accompanying text.

94 In that regard, I have not attempted to assess the findings in terms of statistical significance. 
tute some $99 \%$ of relevant charges and affected employees. I have omitted findings that pertain to formal Board settlement and compliance with ALJ decisions, as those two categories include a de minimis number of charges and employees. Table 1 reports calculations for the average time period using Board charges as the basic unit of measurement.

Table 1: Average Number of Days from Firing to Receipt of Backpay, Based on Charges

\begin{tabular}{|l|c|c|c|}
\hline & Firing to Charge & Charge to Backpay & Total \\
\hline Non-Board Settlement & 31 & 239 & 270 \\
\hline Informal Settlement & 31 & 537 & 568 \\
\hline Compliance with Board & 31 & 1735 & 1766 \\
\hline Compliance with Court & 31 & 2612 & 2643 \\
\hline
\end{tabular}

These findings predictably reflect that discharge victims receive back pay more rapidly in settlements that do not require Regional Office approval than settlements that involve Board participation. Backpay received following litigation takes longer, and - again not surprisingly this backpay is disbursed sooner in order to comply with Board decisions than to comply with appellate court judgments. The same progression, from shortest to longest delay periods, also exists with respect to the hybrid charges covering both non-discharged and discharged victims of unlawful discrimination.

Table 1 also discloses an enormous difference between settled and litigated claims when it comes to the time period from firing to receipt of backpay. The average period for charges that settle ranges from nine months (non-Board settlements) to over eighteen months (informal settlements). By contrast, the average period for charges resolved through compliance with litigated decisions varies from nearly five years (Board decisions) to over seven years (court judgments). ${ }^{96}$

95 For this hybrid group, the average numbers of days are as follows:

\begin{tabular}{|l|c|c|c|}
\hline & Firing to Charge & Charge to Backpay & Total \\
\hline Non-Board Settlement & 31 & 257 & 288 \\
\hline Informal Settlement & 31 & 631 & 692 \\
\hline Compliance with Board & 31 & 1450 & 1481 \\
\hline Compliance with Court & 31 & 2973 & 3004 \\
\hline
\end{tabular}

96 The Board decision and court judgment categories include a relatively small number of cases that involve litigation addressed specifically to contested backpay amounts. See supra notes 84-85 (discussing proportion of charges that result in compliance decisions). For Board decisions, removing 
Table 2 reports the average time period that affected employees wait from date of filing a charge to date of backpay receipt. The calculation of average time periods based on affected employees is consistently higher than when using Board charges as the unit of measurement. Table 2 also reports the percentage increase over the charge-to-backpay period identified in Table 1.

Table 2: Average Number of Days from Filing Charge to Receipt of Backpay, Based on Affected Employees

\begin{tabular}{|l|c|c|}
\hline & Charge to Backpay & Increase from Table 1 \\
\hline Non-Board Settlement & 351 & $47 \%$ (above 239$)$ \\
\hline Informal Settlement & 759 & $41 \%$ (above 537$)$ \\
\hline Compliance with Board & 2229 & $22 \%$ (above 1735$)$ \\
\hline Compliance with Court & 3869 & $48 \%$ (above 2612$)$ \\
\hline
\end{tabular}

The average period from charge to backpay is substantially longer (by $22 \%$ to $48 \%$ ) when calculated on a per-employee rather than a per-charge basis. The most likely explanation is that backpay claims with large numbers of discharged employees are more complex to investigate and prosecute, and also more costly for employers. More complex and costly claims take considerably longer to settle or to litigate, thereby raising the overall average time period in each claims category. ${ }^{97}$ My proposal for a two-tiered mandatory minimum backpay period relies on the findings from Table 1 rather than Table 2. This reliance avoids the risk that the proposed new approach might be unduly influenced by the outcomes in a handful of meritorious claims involving large numbers of employees. Still, it is worth noting that for settled backpay claims involving fired employees, the average employee owed backpay waits between thirteen months and twenty-six months to collect wages; for claims resolved through litigation, the average period of delay endured by affected employees ranges from 6.2 to 10.7

the charges that involve contested backpay proceedings would lower the average period for resolution by about two months - from 1766 to 1697 days. For court judgments, omitting the charges that involve backpay compliance proceedings would lower the average period for resolution by about eleven months - from 2650 to 2319 days.

97 See, e.g., Point Blank Body Armor, Inc., 12-CA-22383-001: non-Board settlement; 203 employees reinstated, 638 days from charge to CCR per employee (versus average of 351 days per employee); Joy Techs. Inc., d/b/a Joy Mining Machinery, 14-CA-26571-001: informal Board settlement; 133 employees reinstated, 2071 days from charge to CCR per employee (versus average of 759 days per employee); O’Neill Meat Co., 288 N.L.R.B. 1354 (1998): compliance with court judgment; 108 employees reinstated, 9473 days from charge to CCR per employee (versus average of 3869 days per employee). 
years. ${ }^{98}$ These results for litigated claims suggest that the delay experienced by the forty-four former Orlando hotel employees is far from exceptional.

In addition to identifying how long discharge victims must wait to receive backpay, I wanted to understand what proportion of meritorious claims - and claimants - receive less backpay than the full amount they are owed by their employer. The full amount is what the Regional Office has calculated should be paid, deducting for interim earnings from other employers and also for any failure to mitigate. ${ }^{99}$ Table 3 reports the results.

Table 3: Backpay Amounts Not Fully Received

\begin{tabular}{|l|c|c|}
\hline & $\begin{array}{c}\text { Percent of Charges with } \\
\text { Full Amount } \\
\text { Not Received }\end{array}$ & $\begin{array}{c}\text { Percent of Employees } \\
\text { Not Receiving Full } \\
\text { Amount }\end{array}$ \\
\hline Non-Board Settlement & $17 \%$ & $20 \%$ \\
\hline Informal Settlement & $9 \%$ & $15 \%$ \\
\hline Compliance with Board & $24 \%$ & $43 \%$ \\
\hline Compliance with Court & $33 \%$ & $39 \%$ \\
\hline
\end{tabular}

Within the subset of settled claims, a somewhat higher proportion of charges, and of affected employees, received less than the full amount owed to them in non-Board settlements than in settlements involving Regional Office participation. Given the Regional Office's diminished role in monitoring and approving non-Board settlements, it seems plausible that more employees will agree to receive a discounted return on their claims.

Table 3 also indicates that for meritorious claims resolved through litigation, two to four times as many charges (and affected employees) receive less than the amounts owed as compared with meritorious claims that settle. This striking difference is initially surprising, because one would assume that Regional Offices generally become less willing to compromise as a case moves from the settlement stage through successive aspects of litigation involving enforcement and compliance. ${ }^{100}$ Upon reflection, however,

98 These figures are a composite of the numbers in the first column of Table 2 combined with the number thirty-one, which reflects my across-the-board calculation for average time between firing and filing of charge.

99 The Regional Office calculates this amount by using interim wage statements from discharged employees along with other records documenting the discriminatees' work search. See OM Memo 0854, attachments B, C and D (2008).

100 See generally Indep. Stave Co., 287 N.L.R.B. 740, 741 (1987) (discussing Board's longstanding policy encouraging pre-litigation settlements); OM Memo 07-27 at 1-2 (2007) (acknowledging Board policy of encouraging settlements, including assessment of whether settlement is "reasonable in light of ... the risks of litigating the issue and the stage of litigation"). 
the sharp increase in proportion of discharged employees receiving less than full backpay seems attributable largely to the element of delay.

When meritorious backpay claims take five to seven years to close, both employers and employees have likely undergone major changes in status and outlook. Employers may have altered their corporate identity, they may have fallen into debt or undergone bankruptcy, or they may be less willing to provide full compensation for workers mistreated by former management years earlier. In addition, employers unwilling to settle prior to a Board or court decision may be more willing to resist paying $100 \%$ of what the law says they owe. As for unlawfully discharged employees, in the course of five or seven years a large number may have died or disappeared from the community with no forwarding address. Discharge victims also may have become frustrated over lengthy delays and abandoned hope or lost interest in receiving what is due to them.

Moreover, notwithstanding the Board's interest in pressing for full backpay amounts during litigation, delays of five to seven years will often erode the accuracy of Board processes for calculating that backpay. Changes in the scope or nature of an employer's operations may result in eliminated positions or reduced comparator hours. And over an extended number of years, employees who have sought or found alternate jobs are likely to experience more layoffs, voluntary quits, or out-of-work periods that further complicate thorough recordkeeping of mitigation efforts. This array of contingent developments presumably makes Regional Offices more willing to compromise. ${ }^{10}$

In terms of the amounts of backpay actually received by this not-fullycompensated subgroup, I determined that for the settled claims categories, employees received $53 \%$ to $58 \%$ of what they were owed in the aggregate; for the litigated claims categories, shortchanged employees received $38 \%$ to $43 \%$ of what was due to them in aggregate terms. ${ }^{102}$ Once again, the substantially lower returns for backpay claimants in litigated cases may well be

101 Two further factors at the appellate court litigation stage likely contribute to reduced levels of backpay. First, many circuits now have mandatory mediation programs, effectively aimed at pressuring the parties to settle. These programs add to existing incentives for Board attorneys to discount backpay amounts given the risk that a court may not uphold the underlying violations. Second, even when the Board prevails on the merits, an appellate court may reduce the award to individual claimants - below what Board attorneys or the full Board concluded was the amount due and owing - based on the court's view of evidence developed during the compliance process.

102 Copies of these findings are on file with the author. In order to minimize the impact of a single case on the smaller datasets for litigated claims, I removed the largest unpaid or underpaid backpay award from each of the two litigation claims categories. Including those two cases would decrease the aggregate proportion paid from $43.5 \%$ to $34 \%$ (Board decisions) and from $38 \%$ to $33 \%$ (court judgments). This would leave the differential between litigated claims and settled claims even more dramatic than what I report in text. 
connected to the fact they do not receive compensation from wrongdoing employers for five to seven years.

The last set of findings concerns differences between the proportion of employees not receiving their full backpay amounts in the "pure discharge" subset as opposed to the hybrid subset that also includes non-discharge unfair labor practices. Table 4 reports these results: the left-hand column is carried over from findings set forth in Table 3.

Table 4: Proportion of Employees Not Receiving Full Backpay Amounts

\begin{tabular}{|l|c|c|}
\hline & $\begin{array}{c}\text { Discharge Victims } \\
\text { Subset }\end{array}$ & $\begin{array}{c}\text { Hybrid Victims } \\
\text { Subset }\end{array}$ \\
\hline Non-Board Settlement & $20 \%$ & $3 \%$ \\
\hline Informal Settlement & $15 \%$ & $5 \%$ \\
\hline Compliance with Board & $43 \%$ & $28 \%$ \\
\hline Compliance with Court & $39 \%$ & $14 \%$ \\
\hline
\end{tabular}

For claims resolved through settlement or following a court judgment, discrimination victims who lost their jobs are three to six times more likely to receive reduced backpay than victims in the hybrid group. ${ }^{103}$ This hybrid group includes a substantial number of individuals receiving backpay for finite periods of lost time or partial wage losses but who remain employees. It seems reasonable to infer that employers are more likely to provide a full backpay award to employees who continue to work for them than to individuals who were fired months or years earlier and are no longer around. That explanation suggests the need for a mandatory minimum award in purely restorative terms with respect to discharge victims.

At the same time, the hybrid group includes many discharged individuals, at least some of whom may have received their full backpay amounts in exchange for not insisting on or not being offered reinstatement. Conversely, a much higher proportion of individuals in the "discharge victims"

103 Discharged individuals whose claims are resolved following a Board decision are 1.5 times more likely to receive reduced amounts than their hybrid-group counterparts. For findings in this Table, I removed several cases involving very large numbers of employees that had a strikingly disproportionate impact on the final numbers. For instance, a single non-Board settlement claim in the hybrid group involved 3600 employees (57\% of the total number of employees in this entire category), all of whom received their full amounts. Including that case would have reduced the hybrid subset proportion not receiving full amounts from $3 \%$ to $1.3 \%$. Conversely, two informal settlement cases where full amounts of backpay were not paid involved 2002 and 1985 employees (together this represented $44 \%$ of employees in the entire category) and a third such case involved $\$ 11$ million owed - 91\% of the total amount owed to employees not receiving their full amounts. Including these three cases would have increased the hybrid subset proportion not receiving backpay from $5 \%$ to $28 \%$. 
subset may have received less than full backpay as part of an arrangement or deal to receive reinstatement. This explanation raises the question whether discharge victims ought to sacrifice as much as one-half to threefifths of backpay amounts owed to them ${ }^{104}$ in order to receive a reinstatement remedy to which they are entitled. To be sure, the Supreme Court recognized the reinstatement remedy as having special public policy value. $^{105}$ But backpay relief also serves important policy-driven objectives, as explained in Part I, and one might be skeptical about a remedial approach that allows such a steep reduction in backpay relief.

\section{Discussion}

\section{Proposal for a Two-Tiered Mandatory Minimum}

A number of salient points emerge from the findings just presented. First, discharged employees must wait a long time to receive backpay owed them by wrongdoer employers. Second, the delay is substantially longer on average anywhere from over three times to nearly ten times as long ${ }^{106}$ when meritorious discharge claims are resolved through litigation rather than settlement. Third, even following these considerable delays, a sizeable number of employees receive in the aggregate one-half to three-fifths less than the backpay amounts the Board has determined are due after accounting for interim earnings and the responsibility to mitigate. And finally, within this group of short-changed backpay recipients, a substantially greater proportion are in connection with claims resolved through litigation as opposed to settlement.

The basic justification for a mandatory minimum backpay period is the same as has been established under Transmarine. Protracted time delays involved in employers' disbursement of backpay owed to unlawfully fired union supporters make it impossible to return to the status quo that existed before the fired individuals experienced months or years of lost backpay. As a further consequence of these extended delays, many "surviving" employees are dissuaded from voicing support for collective bargaining or for

104 See supra text accompanying note 102 (reporting that the not-fully-compensated subgroup received $53 \%$ to $58 \%$ of amounts due in settled claims and $38 \%$ to $43 \%$ of amounts due in claims resolved through litigation).

105 See supra text accompanying notes 47-52 (discussing Board's determination in F.W. Woolworth to elevate remedy of reinstatement for public policy reasons, and Court's respect for that policy-driven position in Seven-Up Bottling).

106 The factor of three reflects the difference between a 575-day average for informal settlements and a 1773-day average for compliance with Board decisions. The factor of ten reflects the difference between a 277-day average for non-Board settlements and a 2650-day average for compliance with court judgments. 
their erstwhile organizing campaign. ${ }^{107}$ Moreover, the costs associated with administering and litigating the remedially appropriate factor of mitigation are in effect being subsidized by discharged employees. Because of delay, fired workers face considerable pressure to settle for less than they are owed and less than what is needed to "effectuate the policies of this Act.",108 Thus, the erosion of the substantial backpay relief that the Court in Phelps Dodge contemplated, as a result of a remedial modification that Phelps Dodge authorized, means the core remedial objective - to eliminate the impairment of section seven rights in the workplace - is not being achieved.

Given these circumstances, an adjustment is needed in order that "the wrongdoer, rather than the victims of his wrongdoing, should bear the consequences of his unlawful conduct."109 A mandatory minimum backpay period would constitute such an adjustment, by creating an incentive for employers to transmit backpay sooner than they now do, and by providing baseline meaningful monetary relief to serve as a modest deterrent against discriminatory discharges. Decades of research have established that employees become disillusioned and less willing to support union organizing campaigns when they observe first-hand the unlawful yet devastating employer response visited upon their co-workers, and then watch as no backpay is received for years. A mandatory minimum backpay award would send a different message to those surviving employees - that every unlawfully fired fellow employee will receive a substantial backpay award directly from the employer.

As for what the precise mandatory minimum period should be, the effort to draw lines inevitably reflects some element of arbitrariness. The basic goal is to allocate more fairly, between wronged employees and wrongdoing employers, the considerable costs associated with Phelps Dodge-generated remedial inquiries. In pursuing this goal, one way to explain the two-week minimum established in Transmarine is in relation to what would have been the reasonable period of days needed to conduct and conclude effects bargaining "in a meaningful manner and at a meaningful time." 110 That period is unlikely to exceed five weeks and may be closer to

107 See supra note 64 and accompanying text (summarizing array of government and scholarly studies addressing negative impact on organizing that results from unlawful discharges and lengthy delays in resolving related claims). See generally Brudney, supra note 4, at 833-34.

10829 U.S.C. $\$ 160(c)$ (2006). See Phelps Dodge v. NLRB, 313 U.S. 177, 191 (1971) (requiring a remedial approach that "pursu[es] the central clue to the Board's powers - effectuation of the policies of the Act") (emphasis added).

109 Transmarine Navigation Corp., 170 N.L.R.B. 389, 389 (1968) (citing to Phelps Dodge).

110 First Nat'l Maint. v. NLRB, 452 U.S. 666, 681-82 (1981) (discussing specifics of duty to bargain over the effects of a plant closing). 
three or four. ${ }^{11}$ Accordingly, the Transmarine choice of two weeks might be viewed as compensating employee victims of bad faith employer misconduct for anywhere from two-fifths to two-thirds the period it would have taken for the employer to avoid such misconduct.

With respect to backpay proceedings, several factors are in play besides an employer's bad faith or intentional misconduct. During a period that ranges on average from nine months to seven years, employees are expected to search for alternate jobs that should reduce somewhat their backpay losses. Moreover, Board delays after a charge is filed - in conducting investigations, in prosecuting complaints, or in pursuing compliance - may contribute to the delayed receipt of backpay, especially for claims resolved through litigation ${ }^{112}$ but occasionally for settled claims as well. Thus the inferred Transmarine ratio of two-thirds to two-fifths the period of avoidable employer misconduct may be too generous toward employees in the instant discrimination setting, and too hard on employers.

My proposal calls for a three-month mandatory minimum with respect to backpay claims resolved through settlement, and a one-year mandatory minimum for claims resolved through litigation. Under this two-tiered approach, employers who resolve meritorious backpay claims against them through settlement would bear a minimum backpay burden covering onethird to one-sixth the average period of time it takes to settle these claims. ${ }^{113}$ Employers who resolve such backpay claims through litigation would bear a minimum burden covering a somewhat lower proportion of the delay period: one-fifth to one-seventh the average time period for securing payment through decisions of the Board or appellate courts. ${ }^{114}$

The lower proportion for claims resolved through litigation recognizes that the Board is more likely to contribute to delays in claims that reach the litigation stage, as these claims involve the potential for bureaucratic bottlenecks or inertia at the national level (before the General Counsel or Board members) as well as in the Regional Office. The Supreme Court has

111 See, e.g., Cent. Transp. Inc. v. NLRB, 997 F.2d 1180, 1188-89 (7th Cir. 1993) (affirming employer's failure to engage in effects bargaining where union proposed series of dates over five weeks and employer never agreed to any of them); Kirkwood Fabricators Inc. v. NLRB, 862 F.2d 1303, 130607 (8th Cir. 1988) (affirming employer's failure to engage in effects bargaining based on presumed standard that employer should "provide a few weeks notice to his employees and bargain with them over such things as pension fund payments, vacation pay, reference letters, extended health care benefits and severance pay so his employees can plan their affairs").

112 See generally NLRB v. J.H. Rutter-Rex Mfg. Co., 396 U.S. 258, 263-64 (1970); NLRB v. Harding Glass Co., 500 F.3d 1, 4-5 (1st Cir. 2007).

113 Table 1 reports that the two major settlement categories take on average nine months and over eighteen months. A three-month minimum is one-third to one-sixth of those averages.

114 Table 1 reports that the two major litigation categories take on average 4.9 years and 7.3 years. A one-year minimum is roughly one-fifth to one-seventh of those averages. 
made clear that the Board "is not required to place the consequences of its own delay, even if inordinate, upon wronged employees to the benefit of wrongdoing employers." 115 Nonetheless, the Board should be permitted to recognize and take some account of these consequences when devising a mandatory minimum backpay award.

At the same time, a considerably longer mandatory minimum in absolute terms is justified on several grounds for litigated backpay claims. These grounds include the extraordinary periods of delay experienced by employees whose claims are resolved through litigation, the substantially higher proportion of these meritorious claimants who do not receive the full amounts owed to them, ${ }^{116}$ and the steeper reductions in amounts actually received by this short-changed group. ${ }^{117}$ Additionally, employees who remain on the job during such a prolonged period inevitably become discouraged about the law's ability to protect and vindicate their section seven rights. They too need to know that employers will be required to provide a meaningful minimum payment of one year's wages to every unlawfully discharged co-worker. In short, this remedy is "designed to restore at least some economic inducement for an employer to [treat union supporters] as the law requires."

\section{Anticipated Concerns}

This two-tiered mandatory minimum proposal will doubtless trigger a series of questions and challenges. I cannot anticipate all such concerns nor is there space to do full justice to the ones I have anticipated. What follows is an effort to identify and respond briefly to a range of concerns that could be raised.

a. It may be argued that imposing a much higher mandatory minimum for claims resolved through litigation abridges employers' rights to due process by punishing employers for exercising their rights of appeal under the NLRA. The Supreme Court has long held that the Act's purposes are remedial, not punitive, and that the language of section 10 (c) must be read with this remedial perspective in mind. ${ }^{119}$ The one-year minimum, however, is not punitive in either intent or effect. Like the remedies in

115 Rutter-Rex, 396 U.S. at 264-65 (emphasis added). It has long been understood that those disproportionately injured by the delay are the employees who did not receive the backpay or benefits to which they were entitled. See id. at 264 (cited with approval in Harding, 500 F.3d at 10).

116 See supra Table 4 (39\% and $43 \%$ versus $20 \%$ and $15 \%$ for settled claims).

117 See supra text accompanying note 102 (reductions of $53 \%$ to $58 \%$ versus $38 \%$ to $43 \%$ for settled claims).

118 NLRB v. Emsing's Supermarket, Inc., 872 F.2d 1279, 1291 (7th Cir. 1989) (discussed supra notes 69,73 and accompanying text).

119 See Republic Steel Corp. v. NLRB, 311 U.S. 7, 10-12 (1940). 
Transmarine and Seven-Up Bottling, it is intended to be deterrent as well as modestly reparative. And the impact of this one-year minimum on litigated claims is entirely proportionate from the combined deterrent-and-reparative standpoint. Employers who choose to contest meritorious discharge and backpay claims through prolonged litigation incur backpay obligations for a smaller proportion of the consequent delay period than is true for employers who choose to settle the meritorious claims against them. Moreover, as explained earlier, the one-year minimum applies to a group of unlawfully fired employees who in the aggregate recover the full amounts owed them far less often, and who are shortchanged to a far greater extent, than unlawfully terminated employees whose claims settle. In sum, the one-year minimum is justified in compensatory and deterrent terms, not as a punitive measure.

b. Another possible concern is that a three-month or one-year guaranteed payment effectively rewards idleness, which is precisely what the duty to mitigate is meant to avoid. But the mandatory minimum is intended to complement rather than supplant the duty to mitigate. Assume, for instance, an unlawfully fired employee who is out of work for eighteen months before his backpay claim settles, and who makes no effort to mitigate for two-thirds of that period - twelve of the eighteen months. Under current law, he might lose two-thirds of the amount he would otherwise have been owed, or twelve months. Under my proposal he would receive three months mandatory minimum and then lose two-thirds of the nonguaranteed amount, or ten of the remaining fifteen months. Admittedly, the employee receives more backpay than he would without a mandatory minimum - that is what a guaranteed baseline payment is supposed to accomplish. But the non-mitigating employee's payments are reduced by the same proportion as is true under existing law.

c. A third criticism is that one-size-fits-all remedies based on empirically constructed averages exceed the Board's remedial authority. The Supreme Court, however, has held otherwise with respect to across-the-

120 To confirm that employers are not penalized for litigating backpay claims, the Board could decide that it will not seek litigation expenses even when the employer offers a frivolous defense. See Unbelievable Inc. v. NLRB, 118 F.3d 795, 801 (D.C. Cir. 1997). But cf. infra text accompanying notes 135-37 (discussing comparisons to Title VII).

121 An employee who is out of work for only three months before a settlement and who fails to mitigate during the entire period would receive a three-month backpay amount that could be viewed as rewarding idleness. But this is very unlikely to occur for two reasons. First, the average delay period of nine to eighteen months means that settlements in three months are rare (and resolution of litigated claims within one year even rarer!). Second, fired employees seeking backpay relief expect to be out of a job for much longer than three months and are likely to believe that shirking from day one will adversely affect their ability to provide for themselves and their families. 
board backpay relief. In Seven-Up Bottling, the Court approved the Board's blanket approach over the objections of various dissenting Justices. ${ }^{122}$ The Court in Sure-Tan did reject a Board mandatory minimum but as the majority explained, that Board proposal was based on a wholly speculative assumption related to the enforcement of a separate federal law by another federal agency. ${ }^{123}$ By contrast, the instant mandatory minimum proposal relies on extensive evidence of current employer practices under the NLRA that result in substantially delayed and reduced monetary relief, combined with decades of accumulated evidence that such delays undermine the effectuation of core policies under the Act. Moreover, with respect to reliance on statistical averaging, the proposal uses established techniques for estimating averages, an approach the NLRB and courts have approved when devising backpay remedies. ${ }^{124}$

d. A fourth and related criticism is that a blanket mandatory minimum does not allow for exceptions. I anticipate at least one exception for discrimination victims who also are undocumented immigrants. This is a group with no rights to backpay under the Supreme Court's decision in Hoffman Plastic Compounds v. NLRB. ${ }^{125}$ Exceptions based on other independently unlawful employee conduct may also deserve consideration.

e. A fifth concern is whether a mandatory minimum is needed at all for settled cases when 80 to $85 \%$ of employees are receiving their full backpay amounts. ${ }^{126}$ There are at least two responses to this concern. One is that the 15 to $20 \%$ of wrongfully discharged employees who settle for less than what they are entitled to receive constitute a sizeable portion of the relevant population. Addressing their legitimate claims is important, especially given that these employees receive less than three-fifths of what they are owed. $^{127}$ Additionally, even the 80 to $85 \%$ receiving what is due to them

122 See supra notes 53-54 and accompanying text.

123 See supra note 59 and accompanying text.

124 See, e.g., CASEHANDling MANUAL, supra note 12, § 10592.5 (authorizing use of statistical sampling to approximate gross backpay when settling cases involving large numbers of discriminatees or long periods of backpay owed); GC Memo 02-04 (2002) (codifying use of statistical sampling in informal settlements and as a basis for compliance specifications and supplemental litigation); Great Lakes Chem. Corp., 323 N.L.R.B. 749 (1997) (approving use of averages to estimate number of discriminates entitled to recover backpay, and relying on wage rates paid to representative employees when computing backpay); Intermountain Rural Elec. Ass'n, 317 N.L.R.B. 588 (1995), enforced, 83 F.3d 432 (10th Cir. 1996) (approving use of averaging of total overtime worked in order to compute lost wages); see also NLRB v. S.E. Nichols of Ohio, 704 F.2d 921 (6th Cir. 1983); Performance Friction Corp., 335 N.L.R.B. 1117 (2001) (approving "representative employee" formulas as basis for computing gross backpay awards). See generally Thorogood v. Sears, Roebuck \& Co., 547 F.3d 742, 748 (7th Cir. 2008) (Posner, J.).

125 Hoffman Plastic Compounds v. NLRB, 535 U.S. 137 (2002).

126 See supra Table 3.

127 See supra note 102 and accompanying text. 
do not get paid for thirteen to twenty-six months following their discharge. $^{128}$ Those payments occur long after most organizing drives have ended, at a time when they can do little to restore employees' belief that the Board is able to protect section seven rights. In short, there are major unmet needs related to the absence of a mandatory minimum in settled cases.

f. A sixth concern is that administering the mandatory minimum will create undue burdens on an agency struggling to apply its remedial backpay authority. The Board already has had to develop almost-encyclopedic guidelines to govern backpay relief, and this proposal represents at most a small addition. If anything, the proposal will alleviate some of the Board's administrative burdens, by simplifying backpay calculations in many instances and by encouraging employers to reduce the time period for resolving backpay disputes.

g. A final concern is that if the mandatory minimum is valuable, it ought to be used for backpay claims against unions as well. Unlawful union conduct at times results in employees being discriminated against and losing pay, ${ }^{130}$ and some version of the mandatory minimum award should presumably apply to union wrongdoers in those settings. At the same time, Board data indicates that $99 \%$ of backpay recipients in the past five years have been victims of unlawful conduct by employers, not unions. ${ }^{131}$ If this proposal is adopted or developed by the Board, data on union misconduct and backpay relief that is subsequently collected and analyzed may form the basis for comparable minimum backpay requirements.

\section{Broadening Perspectives and Augmenting Resources}

In addition to the proposal for a mandatory minimum award set forth in this Part, I suggest the Board may want to take a fresh look at how it administers and enforces back pay relief. The Board's approach on mitigation has been in place for six decades and has served as a model for other

128 See supra note 98 and accompanying text.

129 For example, the Board could make the mandatory minimum payable immediately upon settlement or at the time of a Board decision in the underlying unfair labor practice case. If the Regional Office determines (in litigated cases) that a discriminatee is entitled to more than the minimum, full backpay litigation might follow. This would avoid the problem of discharge victims having to wait through years of compliance investigations and proceedings before receiving any monetary relief.

130 See, e.g., NLRB \& Int'l Ass'n of Ironworkers, Local 480, 466 U.S. 720 (1984).

131 For the five year period, 135,729 employees overall received backpay from employers, and with one highly unusual exception - 1874 employees overall received backpay from unions. The exception was a single informal settlement in FY 2006 in which 2584 individuals received a total payment of $\$ 12,377$ (an average of $\$ 4.79$ per employee). If this one settlement (which covers more employees than all other union backpay charges combined in our five-year period) were included, the ratio of backpay recipients from employers would be $97 \%$ instead of $99 \%$. 
federal statutes adopting a duty to mitigate, notably Title VII. ${ }^{132}$ The Board also has recognized some connection between its own standards and the mitigation practices under state laws that determine eligibility for unemployment insurance (UI) benefits. ${ }^{133}$ Pursuant to detailed Board guidelines and practices, unlawfully discharged employees are expected to make reasonable efforts to search for substantially equivalent work. ${ }^{134}$ The two core issues, therefore, are what qualifies as substantially equivalent work and what satisfies the requirement to conduct a reasonable job search.

Over the years, the Board has not seriously examined either Title VII or state UI statutes to determine whether their parallel provisions offer any useful insights as to when available interim employment is substantially equivalent and what qualifies as a reasonable job search. Given that the Board's approach to backpay and mitigation is viewed by many observers as excessively delayed, unduly contentious, and bureaucratically onerous, it might be valuable - or at least prudent - to consider what lessons can be learned from other statutory schemes. My purpose here is not to offer specific recommendations but rather to suggest in illustrative terms why these parallel statutory schemes warrant more attention.

For example, Title VII caselaw may offer useful insights regarding what is considered substantially equivalent work. Many circuits have interpreted this phrase narrowly to mean that an interim employment option must provide the discriminatee with "virtually identical promotional opportunities, compensation, job responsibilities, working conditions and status"

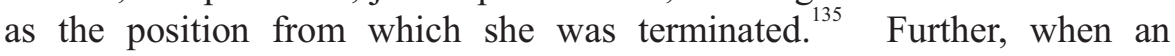
employee takes an inferior job on an interim basis to help make ends meet, she is not obligated to remain in that job during the pendency of her

132 See Ford Motor Co. v. EEOC, 458 U.S. 219, 231-32 (1982) (borrowing liberally from NLRA policies and caselaw in analyzing discriminatees' duty to mitigate under $\S 706$ (g) of Civil Rights Act); Albemarle Paper Co. v. Moody, 422 U.S. 405, 419 (1975) (discussing how the make-whole purpose of Title VII backpay relief was "expressly modeled on the backpay provision of the National Labor Relations Act").

133 See generally Jackson Hosp. Corp., No. S 9-CA-37734, 2008 WL 544882 (NLRB Div. of Judges, Feb. 26, 2008), aff'd, 354 N.L.R.B. No. 42, slip op. at 10 (2009), petition for review filed D.C. Cir. No. 09-1203 (July 14, 2009) (citing Superior Protection Inc., 347 N.L.R.B. No. 105, slip op. at 3 (2006); Birch Run Welding, 286 N.L.R.B. 1316, 1319 (1987)).

134 See CASeHANdling Manual, supra note 12, § 10558.3; GC Memo 09-01 (2008) at 5-7 (discussing elements of proof regarding substantially equivalent available jobs); $i d$. at 7-9 (discussing burden of production that discriminatee conducted a reasonable job search).

135 Vaughan v. Sabine County, No. 03-41216, 2004 WL 1683099 (5th Cir. 2004) (slip op. at 3) (emphasis added); see also Sellers v. Delgado Cmty. Coll., 839 F.2d 1132, 1138 (5th Cir. 1988); Rasimas v. Mich. Dep't of Mental Health, 714 F.2d 614, 624 (6th Cir. 1982); Weaver v. Casa Gallardo, 922 F.2d 1515, 1527 (11th Cir. 1991); Booker, III v. Taylor Milk Co., 64 F.3d 860, 866 (3d Cir. 1995). 
claim. ${ }^{136}$ Importantly, a discriminatee entitled to backpay under Title VII is not required to go into another line of work, or to take a demeaning position or a demotion. ${ }^{137}$ Board guidance addressing the duty to mitigate is more equivocal on this point, suggesting that a discriminatee is "not normally required to accept lower-paying employment."138 It seems worth exploring whether these Title VII decisions and others addressing mitigation reflect a more protective and less burdensome overall stance toward victims of discrimination than has developed under Board doctrine. If so, the result would be somewhat ironic - and perhaps deserving of consideration by the Board - given that Title VII used the NLRA as its original model.

A related empirical question is whether backpay claims under Title VII are subject to extended, closely contested litigation less often than they are under the NLRA. It seems at least plausible that employers' resistance to backpay awards is not as prolonged or intense under a statute that awards attorney's fees and costs to the prevailing party. ${ }^{139}$ Unlike the text of Title VII, section 10(c) of the NLRA makes no provision for the award of attorney's fees to a prevailing party, and Board authority to recover litigation costs has been questioned by appellate courts. ${ }^{140}$ The Board, however, may well retain inherent authority to pursue such costs under the bad faith exception to the American Rule. ${ }^{141}$ If Title VII backpay claims are being resolved more promptly and less contentiously due at least in part to the risk of attorney's fee awards in favor of already-prevailing claimants, the Board may wish to consider more frequent pursuit of litigation costs against employers whose conduct is intended to stall or frustrate the compliance process.

A second, separate area of inquiry involves state law practices under the UI system that may shed relevant light on what constitutes a suitably

136 See Sellers, 839 F.2d at 1137 (relying on Supreme Court's holding in Ford Motor Co. that a Title VII claimant is under no obligation to accept non comparable employment in the first instance, and therefore cannot be required to stay in any such non comparable position).

137 See Brady v. Thurston Motor Lines, 753 F.2d 1269, 1274-75 (4th Cir. 1985) (citing Ford Motor Co., 458 U.S. at 231)

138 CASEHANDling MANUAL, supra note 12, § 10558.3; GC Memo 09-01 (2008) at p. 9 (emphasis added); see also Ford Motor Co., 458 U.S. at 232 n. 16 (citing appeals court decisions from 1950s suggesting that under NLRA law, claimants must consider taking a lower-paying position after seeking work without success for an extended period).

139 See 42 U.S.C. $\$ 2000 \mathrm{e}-5(\mathrm{k})$ (2006).

140 See Quick v. NLRB, 245 F.3d 231, 256-57 (3d Cir. 2001); Unbelievable Inc. v. NLRB, 118 F.3d 795, 800-06 (D.C. Cir. 1997). But cf. id. at 806-12 (Wald, J., dissenting).

141 See Unbelievable Inc., 118 F.3d at 800, 809 (leaving open the issue of Board's inherent authority); Alwin Mfg. Co., 326 N.L.R.B. 646 (1998), enforced, 192 F.3d 133, 142-44 \& n.13 (D.C. Cir. 1999) (awarding litigation costs against employer); see also Teamsters Local Union No.122, 334 N.L.R.B. 1190, 1193-95 (2001) (awarding litigation expenses against union based on bad faith during bargaining and continuing bad faith during litigation of $\S 8(\mathrm{~b})(3)$ claim). 
diligent job search. Under recently promulgated Board guidelines, once it is clear that substantially equivalent jobs are available, the General Counsel has the burden to produce evidence of a reasonable job search by the backpay claimant. ${ }^{142}$ The Board on a number of occasions has held that a wrongfully discharged employee's receipt of unemployment benefits is "corroborative of reasonable efforts to seek interim employment.",

Beyond what is corroborative, however, should the Board consider borrowing from certain UI job search standards as part of an effort to simplify its approach on this issue? When meeting its burden of production, what actions, if any, ought the Board to require of a backpay claimant besides registering at a UI office, meeting periodically with UI staff, and submitting a weekly record of contacts with possible employers? ${ }^{144}$ When unemployed discharge victims take short vacations or enroll in training courses, should such temporary hiatuses from the job search process be at all probative of lack of reasonable diligence? ${ }^{145}$ If, as seems likely, agency and court review of the job search process is less time-consuming and fractious in the UI setting than under Board practice, should the NLRB take a closer look at these state practices? As with Title VII, evidence that UI processes are more efficient and less onerous for claimants would be somewhat ironic. Why should government-administered proceedings under the NLRA tolerate or effectively encourage greater obstacles to recovery for meritorious claimants who are victims of intentional misconduct by their former employers than occurs in government-administered proceedings for UI applicants whose former employers are not wrongdoers under the law?

Finally, in addition to seriously examining how mitigation operates in similar statutory settings, the Board should strongly consider efforts to seek and expend greater resources in the backpay compliance area. For too many years, backpay proceedings have been regarded as of minimal importance in the Board's remedial and policy framework. Memos from the General Counsel establish that securing rapid elections, addressing successorship challenges, or resolving surface bargaining complaints are opera-

142 See St. George Warehouse, 351 N.L.R.B. 961, 961 (2007); GC Memo 09-01 (2008) at 7. The employer retains the ultimate burden of proof that the claimant's search was not reasonably diligent.

143 Jackson Hosp. Corp., No. S 9-CA-37734, 2008 WL 544882 (NLRB Div. of Judges, Feb. 26, 2008), aff'd, 354 N.L.R.B. No. 42, slip op. at 10 (2009), petition for review filed D.C. Cir. No. 09-1203 (July 14, 2009). See, e.g., Superior Prot., Inc., 347 N.L.R.B. 1197, 1198 (2006) (holding that receipt of UI benefits constitutes "prima facie evidence of a reasonable search"); Birch Run Welding, 286 N.L.R.B. 1316, 1319 (1987) (same); Midwest Motel Mgmt. Corp., 278 N.L.R.B. 421, 422-23 (1986) (same).

144 See generally SAMUEl Estreicher \& Gillian LESTER, EMPLOYMENT LAW 150 (2008); U.S.

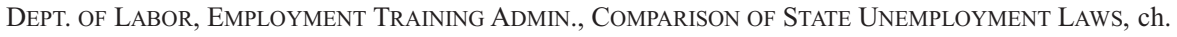
5 (non-monetary eligibility) (2009) (copy on file with author).

145 See Mark A. Rothstein et AL., Employment LaW 850 (3d ed. 2005). 
tional priorities whereas backpay compliance proceedings are backburner items - relegated to second class status if substantial amounts of money are at stake and third class status if only modest amounts are involved. ${ }^{146}$ This neglect of backpay claims is unlikely to change unless additional resources are allocated by Congress to the Board, or re-allocated by the Board within its current budget.

\section{CONCLUSION}

As the labor law community is well aware, Congress has made no substantial changes to the NLRA for over half a century. Prolonged congressional inaction has left the NLRB as the default channel for those seeking to revise or update labor relations policy. It would be understandable if partisan pressures on the Board - resulting inter alia from an increasingly politicized appointments process ${ }^{148}$ - have made the agency less willing to consider or initiate adjustments in the use of its existing powers. What is understandable, however, is not necessarily justifiable.

This Article has focused on backpay claims for wrongful discharge and their significance in effectuating the core policies of the Act. The Court has long made clear that the Board as expert agency has broad discretion when designing and adjusting its remedial powers. In the area of backpay, the Board has the authority to do more than it has done. A mandatory minimum award for wrongfully discharged employees is an important way the Board can move forward, using existing effects-bargaining precedent as a model while invoking the reasoning of Phelps Dodge and its progeny. By adopting a properly modulated and adequately justified mandatory minimum, the Board can help make backpay claims a more meaningful element of the Board's policymaking responsibilities. This type of remedial adjustment is overdue.

146 See GC Memo 98-4 (1998); GC Memo 96-2 (1996); see also supra note 86.

147 The Obama Administration's FY 2011 NLRB budget request includes a very small overall increase of 1.3\%. See Susan J. McGolrick, Proposed Budget for FY 2011 Includes Modest Increases for NLRB, FMCS, NMB, 20 Daily Lab. Rep. (BNA) at AA-6 (Feb. 2, 2010). Accordingly, resource increases may need to come from elsewhere within existing Board allocations.

148 See generally Brudney, supra note 4, at 243-52; Joan Flynn, A Quiet Revolution at the Labor Board: The Transformation of the NLRB 1953-2000, 61 OHIO ST. L.J. 1361 (2000). 